\title{
Viral Particles per Milliliter
}

National Cancer Institute

\section{Source}

National Cancer Institute. Viral Particles per Milliliter. NCI Thesaurus. Code C124474.

A unit for virus amount expressed as the number of viral particles per milliliter. 